\title{
Kedudukan Subsistem Kepolisian dalam Sistem Peradilan Pidana
}

\author{
Chairul Huda
}

\begin{abstract}
Abstrak
The subsystem of police has been a control position in criminal justice system from where the effectiveness of the system has been determined. Therefore, discourses on the position of the subsystem of police has been always interesting to do. Because the changes of function and responsibility of the subsystem will give a great effect on the performance of the system as a whole, reposition of The Police of the Republic of Indonesia (POLRI) recently has to be supported by an andequate and academic responsible teoritical understanding.
\end{abstract}

\section{Pendahuluan}

Setiap kali disinggung mengenai hukum, maka di dalamnya terkandung makna bukan semata-mata mengenai aturan-aturan hukum, tetapi lebih luas lagi meliputi pula lembaga dan pranata hukum, sarana dan prasarana hukum, dan budaya hukum. Perkembangan hukum karenanya bukan hanya berarti berevolusinya aturan perundang-undangan, tetapi meliputi pula tabiat yang lebih luas. Salah satu perkembangan dalam bidang hukum yang cukup menonjol pada Era Reformasi, khususnya yang berkaitan dengan sistem peradilan pidana adalah diadakannya reposisi Polri yang menempatkan lembaga tersebut di luar institusi militer, yang selanjutnya secara bertahap. akan dikembangkan sebagai suatu lembaga yang mandiri. Untuk tahap awat, Polri berada langsung di bawah Departemen Pertahanan dan Keamanan, yang sejalan dengan ke- siapan organisasi, sarana dan prasarana pendukung serta personil diharapkan di kemudian hari menjadi suatu lembaga pemerintah non departemen yang pengendaliannya langsung di bawah Presiden. Hal ini merupakan konsekuensi atas dua tuntutan teoritis. Pertama, kepolisian sebagai bagian tugas pemerintahan, mengharuskan Polri menjadi bagian kekuasaan eksekutif yang mempunyai fungsi, tugas dan tanggung jawab yang sangat berbeda dengan angkatan perang, dan karenanya mesti dipisahkan dari ABRI. Kedua, kepolisian sebagai salah satu subsistem dalam sistem peradilan pidana, mengharuskan Polri menjadi bagian penyelenggara administrasi peradilan pidana, sehingga dirasakan lebih berdaya guna apabila Polri sejajar dengan subsistem-subsistem lain (kejaksaan, pengadilan, dan lembaga pemasyarakatan). 
Sebagai kelanjutan dari adanya tuntutan teoritis untuk mengadakan reposisi Polri sehingga menjadi subsistem yang kedudukan dan wibawanya sejajar dengan subsistem lain, maka perlu dipahami pandangan-pandangan teoritis seputar kedudukan fungsi subsistem kepolisian dalam sistem peradilan pidana. Hal ini mengharuskan untuk sementara waktu pembicaraan dilepaskan dari kenyataan yuridis bahwa di Indonesia Polri-lah yang umumnya bertanggung jawab melaksanakan tugas sebagai subsistem kepolisian. Hal ini juga dimaksudkan untuk menepis kerancuan antara pelaksanaan tugas Polri dan pelaksanaan tugas subsistem kepolisian. Di beberapa negara tanggung jawab subsistem kepolisian dilaksanakan bukan hanya oleh polisi, tetapi juga oleh instansi lain. Di Indonesia dalam hal tertentu (misalnya tindak pidana khusus) fungsi subsistem kepolisian dilakukan oleh instansi bukan Polri, seperti Kejaksaan. Dalam hal ini kejaksaan mempunyai dua tanggung jawab sekaligus, tanggung jawab sebagai subsistem kepolisian dan subsistem penuntutan. Sebaliknya, Polri pun tidak semata-mata bertanggung jawab melaksanakan fungsi subsistem kepolisian dalam hubungannya dengan sistem peradilan pidana, tanpa mengkaitkannya secara langsung dengan POLRI itu sendiri.

Di satu sisi tinjauan ini mempunyai kelemahan, karena tidak bersifat aplikatif. Namun di sisi lain, pengkajian menjadi lebih "leluasa" untuk menerobos ketentuan-ketentuan yuridis dan kenyataan-kenyataan praktis mengenai fungsi kepolisian, sehingga diharapkan di- peroleh gambaran yang lebih baik mengenai subsistem tersebut. Dengan demikian kajian lebih bersifat teori (hukum) daripada dogmatik (hukum). Tampaknya hal ini lebih berguna pada tataran pengambilan kebijakan dalam mempersiapkan kemandirian POLRI.

\section{Subsistem Kepolisian sebagai Gatekeepers Sistem Peradilan Pidana}

Sejauh ini dalam teori telah diakui bahwa kedudukan subsistem kepolisian adalah sebagai gatekeepers atau penjaga pintu gerbang dari sistem peradilan pidana.' Baik sistem peradilan pidana dilihat sebagai suatu rangkaian sistem yang mengalir maupun sebagai suatu rangkaian sistem dalam rangkaian paralel, subsistem kepolisian tetap berposisi demikian. Apabila sistem peradilan pidana dilihat sebagai rangkaian sistem yang mengalir, berarti tekanan diletakkan pada adanya anggota masyarakat yang melanggar aturan pidana dalam perundang-undangan. Asumsi awalnya adalah bagaimana memperlakukan orang yang melakukan perbuatan pidana. Sebaliknya apabila sistem peradilan pidana dilihat sebagai sistem rangkaian yang paralel, berarti tekanan ditempatkan pada adanya perbuatan-perbuatan yang mencocoki rumusan undang-undang yang ditetapkan sebagai perbuatan pidana. Menghadapi dua persoalan ini, sistem peradilan pidana memposisikan subsistem kepolisian sebagai lini terdepannya. Selain itu, orang-orang lain yang sebenarnya tidak langsung berkaitan dengan

John Baldwin dan A. Keith Bottomley (ed). 1978. Criminal Justice; Selected Readings. London: Martin Robertson. HIm. 35. 
suatu peristiwa pidana tertentu, oleh sistem peradilan pidana juga dilibatkan dalam proses yang terjadi pada subsistem kepolisian.

Setiap orang yang berhubungan dengan sistem peradilan pidana, pertama-tama yang bersangkutan akan berhadapan dengan subsistem kepolisian. Anggota masyarakat yang sadar akan tanggung jawab sosialnya apabila mengetahui keberadaan orang lain yang diyakini sebagai pelaku suatu perbuatan pidana mestinya menyampaikan apa yang diketahuinya ifu kepada subsistem kepolisian. Korban yang berhasil melumpuhkan seorang pelaku kejahatan, tidak lantas menghakimi sendiri pelaku perbuatan pidana tersebut, tetapi sebaiknya menyerahkannya kepada subsistem kepolisian. Akibatnya setiap pembuat delik yang memasuki sistem peradilan pidana, pertamatama akan diproses dalam subsistem kepolisian. Dengan demikian, baik anggota masyarakat, korban, maupun pembuat delik ketika bersentuhan dengan sistem peradilan pidana, mereka pertama-tama akan berhadapan dengan (aparat dan) subsistem kepolisian.

Hal ini juga mengandung pemahaman bahwa pada dasamya setiap perbuatan pidana yang diproses dalam sistem peradilan pidana dimulai dari subsistem kepolisian. Anggota masyarakat yang menyaksikan suatu peristiwa pidana, karena tanggung jawab sosialnya pula didorong untuk menyampaikannya kepada subsistem kepolisian. Korban suatu perbuatan pidana mengawali upayanya untuk mencari keadilan pada subsistem kepolisian. Setiap kali terjadi perbuatan yang bertentangan dengan larangan atau keharusan yang ditentukan oleh perundang-undangan, yang di dalamnya disertai dengan ancaman pidana barangsiapa yang melakukannya, maka perbuatan tersebut seyogyanya ditindaklanjuti melalui pemerosesan dalam subsistem kepolisian. Jadi, baik orang maupun perbuatan orang yang berkaitan dengan hukum pidana, lebih khusus lagi, baik orang yang melakukan perbuatan pidana maupun perbuatan pidananya itu sendiri, apabila akan digulirkan masuk ke dalam sistem peradilan pidana pertama-tama akan ditempatkan dan diproses dalam subsistem kepolisian. Dari sanalah berawalnya seluruh rangkaian proses pidana, makanya dia disebut sebagai "pintu gerbang".

Kedudukan strategis subsistem kepolisian yang demikian itu hingga kini oleh para ahli masih diperdebatkan batas-batasnya, sehingga selalu menarik untuk melihat bagaimana kecenderungan pandangan mengenai kedudukan subsistem kepolisian sebagai gatekeepers dalam sistem peradilan pidana dewasa ini.

Kedudukan subsistem kepolisian sebagai gatekeepers proses pidana, pada intinya berhubungan dengan pelaksanaan fungsi represif terhadap perbuatan pidana. Hal ini berpangkal tolak dari bagaimana kinerja subsistem kepolisian dalam melacak terjadinya perbuatan pidana yang menyidik pelakunya. ${ }^{2}$ Dalam hal ini ada dua rangkaian pekerjaan yang meskipun sulit untuk dipisahkan, namun harus dapat dibedakan. Pertama, menemukan dan memastikan apakah suatu perbuatan adalah perbuatan pidana dan menemukan orang yang disangka sebagai

\section{${ }^{2}$ Ibid.}


Chairul Huda. Kedudukan Subsistem Kepolisian dalam...

pembuatnya. Kedua, memproses perbuatan pidana yang terjadi dan pembuatnya tersebut, sehingga terdapat cukup alasan untuk meneruskannya kepada subsistem penuntutan. Baik rangkaian tindakan yang pertama maupun yang kedua, menighadapi dua persoalan yang sangat berkaitan, tetapi harus dapat ditempatkan dalam wadah yang berbeda, yaitu mengenai orang dan perbuatannya.

Umumnya ada tiga cara sampainya suatu perbuatan pidana kepada subsistem kepolisian, yaitu melalui pelaporan, pengaduan masyarakat dan dalam hal pelakunya tertangkap tangan. Masyarakat itu sendiri sangat menentukan hal diterimanya laporan dan aduan suatu perbuatan pidana. Para ahli menyebutkannya sebagai society discretion. Selain itu, menghadapi laporan dan pengaduan masyarakat (dalam teori umumnya disebut sebagai society. complaint), subsistem kepolisian pertama-tama harus memastikan apakah perbuatan yang diadukan dan dilaporkan tersebut perbuatan pidana. Dalam hal ini police discretion bukan sesuatu yang mengadaada, tetapi justru suatu kesungguhan. Dengan demikian, pengetahuan mengenai perbuatan apakah yang masuk kategori sebagai perbuatan pidana, merupakan hal mendasar yang harus dipahami oleh subsistem kepolisian. Meskipun dalam kepustakaan mengenai hal ini masih selalu diperdebatkan, tetapi dalam hal ini subsistem kepolisian mesti berpegang pada pengertian yuridis. Perbuatan pidana adalah perbuatan yang dilarang dan diancam dengan pidana barangsiapa melakukannya. ${ }^{3}$
Pangkal tolaknya adalah adanya suatu larangan oleh perundang-undangan dan mengancam dengan pidana bagi siapa pun yang melanggar larangan tersebut terhadap dilakukannya suatu perbuatan tertentu. Perbuatan di sini dalam arti adanya kelakuan dan kejadian yang ditimbulkan oleh kelakuan tersebut (akibat) yang terlarang. Kelakuan dimaksiud bisa dalam arti melakukan sesuatu maupun tidak melakukan sesuatu. Jadi kelakuan dalam hal ini dapat bersifat dilanggarnya larangan yang ditentukan undang-undang maupun tidak diturutinya perintah yang ditentukan oleh undang-undang.

Untuk menentukan apakah memang telah terjadi suatu perbuatan pidana, mesti ditemukan adanya peristiwa kongkrit (perbuatan) yang taatbestand dengan rumusan delik dalam perundang-undangan. Namun, selain itu perbuatan pidana tersebut harus bersifat melawan hukum (materiil), karena memidana sesuatu yang tidak bersifat melawan hukum tidak ada artinya. ${ }^{4}$ Persoalannya adalah, apakah subsistem kepolisian berwenang untuk menilai suatu perbuatan sehingga dipandang bersifat melawan hukum dan menentukan ada tidaknya alasan-alasan pembenar, alasan yang meniadakan sifat melawan hukum perbuatan pidana. Jika masalah ini dijawab negatif, maka pengertian perbuatan pidana itu sendiri menjadi lonjong, tidak bulat, mengingat sifat melawan hukum selalu menjadi unsur mutlak setiap delik. Apabila dijawab positif, maka subsistem kepolisiän dihadapkan pada suatu tugas penilaian yang begitu seramnya, karena

${ }^{3}$ Roslan Saleh. 1983. Perbuatan Pidana dan Pertanggungjawaban Pidana; Dua Pengertian Dasar

dalam Hukum Pidana. Jakarta: Aksara Baru. HIm. 1.

${ }^{4}$ Roeslan Saleh. 1983. Sifat Melawan Hukum dari Perbuatan Pidana. Jakarta: Aksara Baru. 
mesti dengan sungguh-sungguh memperhatisan rasa kesusilaan masyarakat yang menen\&ukan tentang ketercelaan suatu perbuatan pidana.

Persoalan ini semakin dilematis apabila dihubungkan dengan persoalan hak asasi manusia, dan persoalan efektivitas subsistem kepolisian khususnya dan sistem peradilan pidana pada umumnya. Di satu sisi melepaskan hal dari wewenang subsistem kepolisian sudah barang tentu akan digiring mereka yang melakukan perbuatan yang belum bulat penuh sebagai perbuatan pidana. Pada sisi lain, membiarkan hal itu menjadi wewenang subsistem kepolisian menjadikan lembaga tersebut mencampuri tugas-tugas yudisial hakim.

Terlepas dari persoalan di atas, pada prinsipnya untuk menentukan adanya perbuatan pidana, maka mesti ada perbuatan yang dilakukan seseorang, dimana perbuatan tersebut melanggar larangan atau mengabaikan perintah undang-undang yang disertai dengan ancaman pidana, dan lebih penting lagi perbuatan tersebut diketahui oleh (aparat) subsistem kepolisian. Berdasarkan alasan-alasan tersebut dapat dipahami bahwa tidak semua perbuatan pidana sampai diketahui oleh pihak kepolisian dan karenanya penegakkan hukum pun tidak dapat dilakukan. Muladi menyebut hal ini sebagai area. of no enforcement. ${ }^{5} \mathrm{Na}$ mun demikian dalam penegakkan hukum subsistem kepolisian tidak boleh hanya meng- andalkan laporan dan pengaduan masyarakat. Adakalanya dia sendiri harus mengintai terjadinya kejahatan dan berusaha menemukan tersangkanya.

Subsistem kepolisian tidak hanya dapat bersikap reaktif atas adanya laporan dan pengaduan masyarakat, tetapi juga harus proaktif segala potensi yang menimbulkan kejahatan. Menurut $H$. Sacks dalam hal ini polisi mesti memperhatikan hal-hal yang tidak biasa, yaitu harus menduga kemungkinan timbulnya kriminalitas dari berbagai aktivitas masyarakat di tempat umum. ${ }^{6}$ hal senada dikemukakan oleh AJP. Butler yang melihat ini sebagai kewajiban polisi untuk memperhatikan dengan. seksama perubahan-perubahan lingkungan. yang terjadi, yang mencurigakan akan menimbulkan kejahatan. ${ }^{7}$ Formulasi teoritis yang ditawarkan Michael Chatterton mengenai hal ini adalah police from wheel and not just on wheels and to spend of his shift patrolling his beat on foot, inspecting the front and rear of vulnerable property and checking on persons who arouse his suspicious. ${ }^{8}$ Dengan demikian, polisi tidak hanya menunggu di atas kendaraannya sampai adanya pergantian waktu tugas, tetapi juga harus beranjak untuk memeriksa hal-hal mencurigakan yang dapat menimbulkan kejahatan.

Hal demikian diperlukan mengingat sebagai suatu sistem peradilan pidana merupakan sistem yang terukur. Efisiensi sistem per-

5Muladi. 1995. Kapita Selekta Sistem Peradilan Pidana. Semarang:Bp. Undip. HIm. 17.

${ }^{6} \mathrm{H}$. Sacks. 1967. "Methods in Use for the Production of a Social Order: Amethod for Warrantably Inferring Moral Character". Dalam D.J. Bordua (ed) The Police: Six Sociological Essays. Wiley. Him. 75.

${ }^{7}$ A.J.P.Butler. 1984. Police Management. Aldershot: Gower. Hlm. 27.

'Michael Chatterton. "Police in social control". Dalam Baldwin dan A. Keit Bottomley (ed). Op. Cit. . HIm. 43. 
adilan pidana salah satu di antaranya ditentukan oleh sampai berapa jauh subsistem kepolisian dapat mengungkap suatu perkara. Perlu ditegaskan di sini perkara-perkara dimaksud adalah perkara-perkara yang diketahui polisi atau recorded crimes, baik berdasarkan laporan atau pengaduan korban atau masyarakat, hasil tangkapan (tertangkap tangan) maupun hasil pengintaian oleh aparat kepolisian. Oleh karena itu, partisipasi masyarakat (citizen complaint) sangat penting dalam menentukan tingkat pengungkapan perkara dimaksud. ${ }^{9}$ Dalam teori hal ini disebut sebagai clearence rate perkara oleh aparat kepolisian. Menurut Jerome $H$. Skolnick clearente rate adalah presentase kejahatan yang diketahui polisi dan diyakini telah dipecahkan..$^{10}$

Bagi polisi, berkenaan dengan fungsi represifnya terhadap kejahatan adalah mengupayakan agar setiap perkara yang diserahkan kepadanya secepat mungkin dapat clear atau terungkap. Kecepatan jajaran kepolisian untuk mengungkap suatu perkara secara keseluruhan sangat menentukan kinerja subsistem kepolisian. Griffin berkaitan dengan hal ini menyatakan bahwa clearence rate merupakan pertanda penting efisiensi kepolisian'secara keseluruhan. "Jadi efisien atau tidaknya subsistem kepolisian sangat ditentukan oleh bagaimana tingkat pengungkapan perkara atau clearence rate yang dilakukan subsistem ini. Bahkan Wilson memandang bahwa clearente rate juga dapat dilihat sebagai alat pengendali atas manajemen kepolisian dan profesionalitas pelaksanaan tugasnya. ${ }^{12}$

Persoalan berikutnya adalah bagaimana proses selanjutnya setelah suatu kejahatan diketahui polisi. Hal ini merupakan sesi kedua dari fungsi represif subsistem kepolisian lebih banyak diwarnai oleh partisipasi masyarakat dalam merespon kejahatan, maka pada sisi lain lebih banyak ditentukan oleh profesionalitas aparat kepolisian dalam menangani kejahatan. Dalam hal ini aparat kepolisian harus dapat menemukan factual guilt atas perkara kejahatan yang dihadapi.

Sesi kedua fungsi represif kepolisian setidaknya terdiri atas tiga rangkaian tindakan. Pertama, polisi harus mencari sejumlah informasi yang dapat mendukung suatu kesimpulan bahwa peristiwa yang terjadi memang suatu tindak pidana. Informasi tersebut dapat diperoleh dari korban kejahatan, ataupun orang-orang lain yang mengetahui tantang beberapa keadaan yang menjurus pada sangkaan telah terjadinya suatu tindak pidana. Adakalanya informasi ini diperoleh dari berbagai bekas yang ditinggalkan di tempat kejadian perkara. Dalam hal ini kepolisian dapat menggunakan berbagai ilmu pengetahuan pembantu pengungkapan kejahatan, seperti kedokteran kepolisian yang meliputi kedokteran forensik, odontologi forensik dan psikiatri forensik. Rangkaian tindakan yang kedua adalah upaya untuk menemukan siapa tersangka pelakunya. Beberapa ilmu pengeta-

Jerome H. Skolnick. 1966. Justice Without Trial; Law Enforcement in Democratic Societis. New York: Jhon Wiley \& Sons Inc. HIm. 168.

: olbid

"Jhon Griffin. 1958. Statistic Essential for Police Efficiency. Springfield: Charles G. Thomas. Him. 69. ${ }^{12}$ OW. Wilson. Police Planning. 1962. Springfield: Charles G. Thimas. HIm. 112. 
huan pembantu yang tergabung dalam kedokteran forensik maupun ilmu pengetahuan lain seperti, ilmu tentang racun, sidik jari dan balistik tetap diperlukan. Hal ini seyogyanya didukung oleh komputer kepolisian, yang memberikan jumlah data kriminal yang berkaitan dengan pelaku kejahatan, pola-pola kejahatan atau modus operandi dilakukannya suatu kejahatan. Ketiga adalah rangkaian tindakan yang dilakukan polisi setelah ditemukannya tersangka pelaku kejahatan tersebut. Tahap ini merupakan tahap yang paling krusial, karena biasanya dibarengi dengan upaya-upaya paksa. Krusial bagi tersangka maupun bagi aparat kepolisian, karena dalam kejahatan-kejahatan kekerasan yang mendominasi statistik kriminal, kemungkinan terjadinya tindak kekerasan (baku tembak, perkelahian, saling kejar-mengejar dengan menggunakan kendaraan, dan lain-lain) sangat besar.

Dalam menemukan factual guilt tersangka; terutama'dalam delik dolus, diperlukan adanya motif (alasan dilakukannya kejahatan, waktu (kesempatan dilakukannya kejahatan)) dan modus (cara dilakukannya kejahatan). Untuk memperoleh factual guilt demikian, tehnik investigasi yang memandang tersangka sebagai objek pemeriksaan sudah tidak dibenarkan lagi, melainkan tersangka mesti dijadikan subjek pemeriksaan. Oleh karenanya perlu dikembangkan scientific investigation, dengan memanfaatkan criminal intelligence, kesabaran, crowd control, dan riot control, forensic sciences dan teknologi kepolisian lainnya. Hal ini sangat menentukan tingkat profesionalitas subsistem kepolisian dalam menangani kejahatan.
Setelah didapat cukup informasi tentang kejahatan dan terșangka pelakunya, perkara tersebut sebenarnya siap diteruskan ke penuntut umum untuk dituntut ke pengadilan.

\section{Goal Prevention Officer}

Gambaran organisasi kepolisian di muka apabila dikaitkan dengan kedudukan subsistem kepolisian sebagai gatekeepers dari sistem peradilan pidana, menyebabkan tidak dapat ditafsirkannya secara sempit kedudukan tersebut. Kepolisian sebagai gatekeepers sistem peradilan pidana bukan semata-mata berarti bahwa fungsi kepolisian adalah menanggulangi kejahatan. Artinya subsistem kepolisian akan berhadapan dengan kejahatankejahatan yang telah terjadi, dan karenanya harus ditanggulangi. Namun selain itu subsistem kepolisian juga harus memainkan peran lain terhadap kejahatan, yaitu menghadapi kejahatan-kejahatan yang belum terjadi. Di sini subsistem kepolisian berfungsi sebagai agen pencegahan kejahatan.

Fungsi subsistem kepolisian sebagai pencegah terjadinya kejahatan diharapkan dapat dimainkan lebih luàs, sesuai dengan adagium mencegah lebih baik daripada mengobati. Hal senada dikemukakan oleh EH. Glover bahwa, the primary object of an officient police is the prevention of crime; the next that of detective and punishment of offenders if crime is comitted. ${ }^{13}$ Dengan demikian berkenaan dengan kejahatan, subsistem kepolisian sebagai gatekeepers sistem peradilan pidana seyogyanya berfungsi baik preventif maupun refresif, dan fungsi

\section{HIm. 92.}

${ }^{13} \mathrm{EH}$. Govler. 1943. "The English Police its Origin and Development" dalam Police Chronicle. London. 
preventif semestinya mendapat perhatian yang. lebih besar.

Hal penting yang perlu dicatat adalah, apabila peran pencegahan kejahatan ingin diberi porsi yang lebih besar dalam pelaksanaan fungsi subsistem kepolisian, maka pencegahan kejahatan itu sendiri harus dijadikan tujuan utama dari sistem peradilan pidana. Apabila pencegahan kejahatan itu sendiri harus dijadikan tujuan utama dari sistem peradilan pidana. Apabila pencegahan kejahatan telah dijadikan tujuan dari sistem peradilan pidana, maka sesuai dengan konsep sistem peradilan pidana sebagai tujuan bersama yang terpadu, hal itu harus benar-benar dipahami oleh subsistem-subsistem dalam sistem peradilan pidana sebagai tujuan bersama yang harus dicapai' secara bersama pula. Subsistem kepolisian sebagai gatekeepers memainkan peran yang menentukan. $\mathrm{Hal}$ ini menyebabkan perlu diadakannya reorganisasi kepolisian, sehingga fungsi preventif dan represif dapat dimainkan secara proporsional. Reorganisasi ferutama dilakukan dalam sistem perekrutan, pendidikan dan restrukturisasi badan kepolisian itu sendiri, sehingga terbentuk satu kesatuan polisi yang tidak hanya terampil mengambil tindakan setelah terjadinya kejahatan, tetapi juga mampu mencegahnya. Berkaitan dengan ini setidak-tidaknya pejabat-pejabat kepolisian yang ada harus lebih banyak dan dapat ditugaskan untuk mencegah terjadinya kejahatan. Apabila memang demikian maka subsistem kepolisian juga ber- kedudukan sebagai goal prevention officer. ${ }^{14}$ Aparat kepolisian semestinya juga dipandang sebagai pejabat yang tujuan pelaksanaan tugasnya adalah pencegahan kejahatan. Tanpa hal ini maka kepolisian akan lebih terfokus pada pekerjaannya yang konvensional, yaitu menyelidik dan menyidik kejahatan.

Menempatkan subsistem kepolisian tidak semata-mata sebagai penyelidik dan penyidik kejahatan, melainkan juga sebagai pejabat yang bertugas mencegah terjadinya kejahatan, menyebabkan subsistem kepolisian dihadapkan pada pekerjaan yang berada di luar tugasnya yang tradisional. Kepolisian juga bertugas untuk mengupayakan tercapainya tujuan (goai) masyarakat, yang menjadi kajian bidang kebijaksanaan kriminal.

Kepolisian dipandang mempunyai fungsi preventif telah diakui sejak lama. Setidaknya Van Vollenhoven pernah menyatakan bahwa, fungsi polisi itu menjalankan preventive rechtzorg yaitu memaksa penduduk suatu wilayah mentaati ketertiban hukum serta mengadakan penjagaan sebelumnya (preventif) supaya tertib masyarakat tetap terpelihara"..$^{15}$ Namun dikaitkannya fungsi preventif ini dengan pendekatan kebijakan (policy approach) merupakan konsep yang relatif baru. Adam Crawford berpendapat bahwa, pencegahan kejahatan ditempatkan sebagai tujuan utama kebijakan dan diintegrasikan ke dalam tugas kepolisian mulai diperhatikan orang pada akhir tahun 1950-an, ${ }^{16}$ yang merekomendasikan diadakannya pelatihan khusus bagi aparat

${ }^{14}$ Linda Harvey. Penny Grimshaw dan Ke Pease. 1989. "Crime Prevention Delivery: the work of crime prevention officers" dalam Rod Morgan dan David J Smith (ed). Coming to term with policing. London: Routledge. HIm. 83.

${ }^{15}$ E Utrecht. 1960. Pengantar Hukum Administrasi Negara Indonesia. Jakarta: Ichtiar. HIm. 60.

${ }^{16}$ Adam Crawford. 1997. The Local Governance of Crime. Oxford: Clarendon Press. HIm. 26. 
kepolisian sehingga menjadi ahli di bidang pencegahan kejahatan. Selain itu diperkenalkan pula partnership approach yang menekan keterlibatan organisasi di luar kepolisian untuk bersama-sama bertanggung jawab dalam pencegahan kejahatan. Perkembangan pada tahun 1970-an telah dibentuk unit khusus di berbagai organisasi kepolisian yang bertugas mengadakan pencegahan kejahatan (Crime Prevention Department). ${ }^{17}$

Dari uraian di atas, terlihat bahwa subsistem kepolisian dewasa ini dituntut untuk dapat berfungsi tidak hanya berkenaan dengan tugastugasnya yang tradisional (menyidik kejahatan), tetapi lebih jauh sifatnya sehingga juga bertanggung jawab terhadap terwujudnya tujuan masyarakat yang telah ditetapkan. Dalam hal ini subsistem kepolisian tidak hanya sebagai gatekeepers sistem peradilan pidana, tetapi juga menjadi goal prevention officers. Hal ini mengharuskan pelaksanaan tugas kepolisian tidak semata-mata dilakukan sebagai reaksi atas terjadinya kejahatan, namun harus lebih banyak dilakukan secara proaktif mengendalikan kejahatan.

\section{Police Waiver dan Sistem Peradilan Pidana}

Dewasa ini sistem peradilan pidana di berbagai negara, telah diterima secara resmi pandangan bahwa peradilan pidana bukanlah satu-satunya cara menyelesaikan masalah kejahatan. Bahkan suatu "penyimpangan" ( $d$ version) yang diakukan oleh polisi dan pe- nuntut umum terhadap suatu kejahatan sering kali dipandang lebih baik.

Diversion tidak mementingkan dikeluarkannya putusan oleh pengadilan (pidana). Diversion bukan berarti menghindarkan terdakwa dari penjatuhan pidana perampasan kemerdekaan, dengan mengupayakan penjatuhan hukuman-hukuman alternatif. Namun lebih jauh lagi, diversion menghindarkan terdakwa dari proses peradilan pidana. Dalam teori diversion yang dilakukan oleh polisi disebut sebagai police waiver.

Terdapat sejumlah cara yang memungkinkan pembuat delik dapat terhindar dari penuntut pidana. Dalam teori mekanisme yang formal adalah peringatan polisi (Police Caution). Andrew Sanders menekankan bahwa sistem peradilan pidana bèrtujuan menghindari adanya stigma. Sanders mengadakan suatu pengamatan di Cumbria daerah yang mungkin untuk perluasan diversion. ${ }^{18}$ Polisi memilih anak-anak yang melakukan delik untuk ditawarkan mengadakan perbaikan terhadap korban (minta maaf, ganti kerugian atau CSO). Jika sepakat, program akan diteruskan sehingga tidak dituntut pidana. Kelemahan sistem ini cukup membahayakan, yaitu dapat membuat polisi sebagai penuntut umum, ha$\mathrm{kim}$, dan sekaligus pelaksana putusan.

Pernah pula diusulkan dalam kepustakaan adanya caution plus, yaitu peringatan yang diberikan dengan syarat-syarat tertentu, seperti penetapan suatu pembinaan yang tidak ditentukan jangka waktunya, partisipasi atau rencana pengobatan. Program ini dijalankan

${ }^{17} \mathrm{lbid}$. Hlm. 27.

${ }^{18}$ Andrew Sanders. 1986. "Diverting Offenders from Prosecution; Can We Leran from of the Countries?" dalam Justice of Peace. Him. 614. 
dalam tingkat lokal, yang umumnya diterapkan terhadap anak-anak.

Penyelesaian perkara tanpa penuntutan pidana secara bersyarat misalnya diadakan dengan kesepakatan bersama tersangka bahwa tidak akan diadakan penuntutan pidana, namun tersangka diwajibkan membayar sejumlah uang tertentu. Hal demikian ini dikenal sebagai transactie. ${ }^{19}$ Tidak membayar ketetapan transactie akan menyebabkan tersangka menghadapi tuntutan yang lebih besar dari penuntut umum, dan juga dalam teori dimungkinkan adanya panggilan meskipun penuntut umum juga memiliki hak melepaskan perkara waiver dalam tahap ini.

Police waiver didasarkan pada faktor individual seperti usia, baru pertama kali melakukan delik dan delik yang dilakukan tidak serius; dan dapat pula didasarkan atas pertimbanganpertimbangan kebijakan kriminal. Tidak benar apabila melihat transactie merupakan kesepakatan antara polisi dengan tersangka terhadap delik yang dilakukannya, untuk membeli pelepasan hak atas pengadilan. Secara formal transactie bukan suatu pidana yang dijatuhkan, tetapi hal itu merupakan usulan polisi yang diterima pembuat delik. Hal ini didasarkan asumsi ancaman denda yang lebih besar apabila perkara dibawa ke pengadilan dan rasa takut akan proses peradilan.

\section{Simpulan}

Dari uraian di atas, terlihat betapa tuntutantuntutan teoritis terhadap pelaksanaan fungsi subsistem kepolisian sangat luas dan berwarna. Dikatakan sangat luas mengingat wilayah kerja subsistem tersebut telah memasuki stadia kebijakan, gunakan memperhatikan. tuntutan baru tujuan sistem peradilan pidana. Selain itu, pandangan demikian mengharuskan subsistem kepolisian lebih proaktif hunting to crimes (criminals) mengingat adagium mencegah lebih baik daripada mengobati. Dikatakan Betwarna mengingat tuntutan aktual terhadap subsistem kepolisian menyebabkan meluasnya kekuasan diskresi yang ada pada lembaga tersebut. Keleluasaan ini menyebabkan keabsahan pelaksanaan fungsi subsistem sedikit banya menjadi subyektif.

Hal ini mengharuskan predikat profesional bukan semata-mata menjadi tuntutan, melainkan suatu keharusan bagi aparat sistem peradilan pidana umumnya, dan khususnya aparat kepolisian. Pemahaman dan pengejawantahan hal ini tidak semata-mata bersifat yuridis, tetapi bidang-bidang lain khususnya pendekatan kebijakan.

Bagaimana halnya POLRI? Itu persoalan lain, yang akan penulis bicarakan dalam tulisan tersendiri. ב

${ }^{19} / \mathrm{bid}$. 


\section{Daftar Pustaka}

Baldwin, John dan A. Keith Bottomley (ed). 1978. Criminal Justice; Selected Readings. London: Martin Robertson.

Bordur, D.J. (ed). 1967. The Police: Six Sosiological Essays. London: Wiley.

Butler, A.J.P. 1984. Police Management. Aldershot: Gower.

Crawford, Adam. 1997. The Local Governance of Crime. Oxford: Clarendon Press.

Griffin $_{i}$ John. 1958. Statistic Essential for Police Efficiency. Springfield: Charles G. Thomas.

Muladi. 1995. Kapita Selekta Sistem Peradilan Pidana. Semarang: Bp. Undip.

Morgan, Rod dan David J. Smith (ed). 1989. Coming to Term with Policing. London: Routledge.

OW. Wilson. 1962. Police Planning. Springfield: Charles $\mathrm{G}$. Thimas.
Rod Morgan dan David J Smith (ed). 1989. Coming to term with policing. London: Routledge.

Saleh, Roslan. 1983. Perbuatan Pidana dan Pertanggungjawaban Pidana; Dua Pengertian Dasar dalam Hukum Pidana. Jakarta: Aksara Baru.

1983. Sifat Melawan Hukum dari Perbuatan Pidana. Jakarta: Aksara Baru.

Skolnick, Jerome H. 1966. Justice Without Trial; Law Enforcement in Democratic Societis. New York: Jhon Wiley \& Sons Inc.

Utrecht, E. 1960. Pengantar Hukum Administrasi Negara Indonesia. Jakarta: Ichtiar.

Justice of Peace. No. 71. Pebruari 1986.

Police Chronicle. 4th edition 1943. 